\title{
Streptomyces shaanxiensis sp. nov., a blue pigment-producing streptomycete from sewage irrigation soil
}

\author{
Yan Bing Lin, Xin Ye Wang, Hui Fang, Ya Nan Ma, Jing Tang, Ming Tang \\ and Ge Hong Wei
}

Correspondence

Ge Hong Wei

weigehong@yahoo.com.cn
College of Life Sciences, State Key Laboratory of Crop Stress Biology for Arid Areas, Northwest A \& F University, Yangling, Shaanxi 712100, PR China

\begin{abstract}
A novel isolate belonging to the genus Streptomyces, strain CCNWHQ $0031^{\top}$, was isolated from soil in a sewage irrigation area in Shaanxi province, China. The isolate produced light greyish-blue aerial mycelium and dark blue diffusible pigment on Gause's synthetic agar. Strain CCNWHQ $0031^{\top}$ formed Spirales-type chains with spiny spores. Chemotaxonomic data confirmed that strain CCNWHQ $0031^{\top}$ belonged to the genus Streptomyces. Analysis of the almost complete 16S rRNA gene sequence placed strain CCNWHQ $0031^{\top}$ in the genus Streptomyces where it formed a distinct phyletic line with recognized Streptomyces species. Strain CCNWHQ $0031^{\top}$ exhibited highest sequence similarities to Streptomyces caeruleatus GIMN4.002 ${ }^{\top}$ (99.3\%), Streptomyces coeruleorubidus NBRC $12855^{\top}(98.9 \%)$, Streptomyces curacoi NBRC $12761^{\top}$ (98.8\%) and Streptomyces lincolnensis NBRC 13054 ${ }^{\top}$ (98.0\%). DNA-DNA hybridization studies of strain $\mathrm{CCNWHQ} 0031^{\top}$ with these four closest relatives showed relatedness values of $56.6 \pm 0.4,50.3 \pm 0.6,49.8 \pm 0.7$ and $36.9 \pm 0.9 \%$, respectively. On the basis of its molecular and physiological properties, it is evident that strain CCNWHO $0031^{\top}$ represents a novel species of the genus Streptomyces, for which the name Streptomyces shaanxiensis sp. nov. is proposed. The type strain is CCNWHQ $0031^{\top}\left(=\right.$ CCNWTJ $0031^{\top}=\mathrm{JCM} 16925^{\top}=$ ACCC $\left.41873^{\top}\right)$.
\end{abstract}

The genus Streptomyces was proposed by Waksman \& Henrici (1943). Streptomyces species are abundant in terrestrial environments and can be easily isolated under laboratory conditions. Members of the family Streptomycetaceae have attracted great attention because they produce various natural products with considerable potential commercial value (Bérdy, 2005). Some Streptomyces species producing blue spores have been reported previously by Trejo \& Bennett (1963). Actinorhodin-related blue pigments have been reportedly produced by Streptomyces coelicolor A3(2) (Bystrykh et al., 1996); blue pigment production has been studied most in S. coelicolor. In addition, two Streptomyces species able to produce blue or violet-blue diffusible pigment have been reported by Zhu et al. (2007, 2011). Meyers et al. (2003, 2004) reported two other Streptomyces species with blue substrate and aerial mycelia. Microbes producing blue pigments are rare (Margalith, 1992) and these natural pigments could be used in the food industry due to their

Abbreviations: DAP, diaminopimelic acid; ISP, International Streptomyces Project.

The GenBank/EMBL/DDBJ accession number for the 16S rRNA gene sequence of strain CCNWHO $0031^{\top}$ is FJ465151.

Two supplementary figures are available with the online version of this paper. solubility, colouring, stability, safety and commercial potential (Pszczolla, 1998).

During our research into new actinobacterial resources, morphological, physiological, chemical and phylogenetic data were determined for isolate CCNWHQ $0031^{\mathrm{T}}$, which was shown to represent a novel species of the genus Streptomyces.

Strain CCNWHQ $0031^{\mathrm{T}}$ was isolated using a dilution plating method from a soil sample in a sewage irrigation

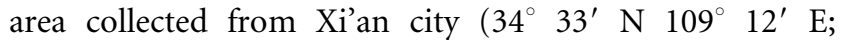
altitude of $425 \mathrm{~m}$ ), Shaanxi province, north-western China, in September 2007. Gause's synthetic agar medium (Atlas, 1993) was used for strain isolation.

Morphological properties were examined by light microscopy (Olympus CX31) and scanning electron microscopy (JSM $6360 \mathrm{LV}$ ) of cultures grown on Gause's synthetic agar medium for 14 days. Electron micrograph preparation was carried out as described by Eguchi et al. (1993). Cultural characteristics were determined after 2 weeks' incubation at $28{ }^{\circ} \mathrm{C}$ on various cultivation media, according to the methods of the International Streptomyces Project (ISP; Shirling \& Gottlieb, 1966). Colours were determined as described by Kelly (1964).

The diaminopimelic acid (DAP) isomer and whole-cell sugar compositions were analysed using TLC according to 


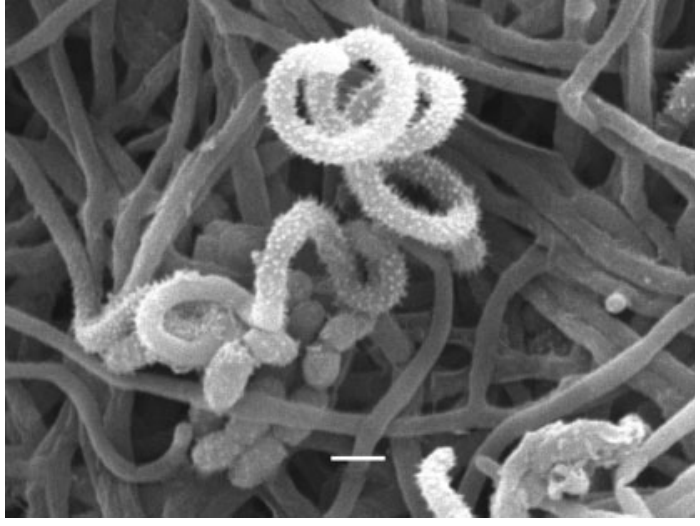

Fig. 1. Scanning electron micrograph of the spiral spore chains and spiny spores of strain CCNWHQ $0031^{\top}$ after 12 days at $28^{\circ} \mathrm{C}$ on Gause's synthetic agar medium. Bar, $1 \mu \mathrm{m}$.

the procedures described by Lechevalier \& Lechevalier (1980). Menaquinones were extracted and determined by HPLC using the methods of Collins (1985). Phospholipid fatty acids were extracted and the constituents were separated by two-dimensional TLC and identified using the procedure of Minnikin et al. (1977). Fatty acids were extracted as described by Kämpfer \& Kroppenstedt (1996). Fatty acid methyl esters were analysed by GC following the MIS operation manual (MIDI), and identified and qualified by the Sherlock MIS software (version 4.5). The DNA $\mathrm{G}+\mathrm{C}$ content was determined using the thermal melting protocol (Marmur \& Doty, 1962), with Escherichia coli $\mathrm{K}-12$ as the standard. DNA-DNA relatedness was determined in triplicate by the initial renaturation rate method (De Ley et al., 1970).

Utilization of carbon and nitrogen sources was determined by using the methods of Gordon \& Mihm (1962) and Tsukamura (1966). Other phenotypic characteristics were tested by using standard procedures (Goodfellow, 1971; Williams et al., 1983). Tolerances to temperature $\left(20,28,37\right.$ and $\left.45{ }^{\circ} \mathrm{C}\right)$ and $\mathrm{pH}\left(5-12\right.$, incubated at $\left.28{ }^{\circ} \mathrm{C}\right)$ were determined on Bennett's agar plates after 2 weeks of incubation.

Genomic DNA extraction and PCR amplification of the $16 \mathrm{~S}$ rRNA gene were carried out following the procedures of Chun \& Goodfellow (1995). Universal bacterial $16 S$ rRNA gene primers [forward primer P1 (5'-CGGGATCCAGAGTTTGATCCTGGCTCAGAACGAACGCT-3') and reverse primer P6 (5'-CGGGATCCTACGGCTACCTTGTTACGACTTCACCCC-3')] were used for 16S rRNA gene amplification. The PCR product was purified and sequenced directly using an automated DNA sequencing system (ABI 3730XL). The $16 \mathrm{~S}$ rRNA gene sequence of the strain was aligned using CLUSTAL_X version 1.8 (Thompson et al., 1997) with the sequences of type strains of recognized species of the genus Streptomyces obtained from the EzTaxon server (http://www.eztaxon.org) (Chun et al., 2007). Phylogenetic trees were reconstructed using the neighbour-joining (Saitou \& Nei, 1987), minimumevolution (Rzhetsky \& Nei, 1993) and maximum-parsimony (Fitch, 1971) methods in the TREECON software package version 1.3b (Van de Peer \& De Wachter, 1994) and the MEGA3.1 software package (Kumar et al., 2004). The genetic distance matrices were estimated by the Kimura twoparameter model (Kimura, 1980). Tree topology was evaluated by bootstrap analysis based on 1000 replicates (Felsenstein, 1985).

The isolate formed a highly branched substrate mycelium and aerial hyphae which differentiated into spiral spore chains with spiny spores (Fig. 1). Strain CCNWHQ 0031 ${ }^{\mathrm{T}}$ grew well on ISP 2, ISP 3, ISP 4, Bennett's agar and Gause's synthetic agar medium. It exhibited moderate growth on nutrient agar and Czapek agar media, but poor growth on ISP 5. Different coloured diffusible pigments were produced on the various test media listed in Table 1. Noticeably, the strain produced large quantities of dark blue diffusible pigment on Gause's synthetic agar medium.

Strain CCNWHQ $0031^{\mathrm{T}}$ mainly contained mannose, arabinose and small quantities of xylose in its whole cell hydrolysate. The whole cell hydrolysate also contained LLDAP, traces of meso-DAP and glycine, indicating that the strain had cell wall type I (Lechevalier \& Lechevalier, 1970). Fatty acid analysis showed that strain CCNWHQ $0031^{\mathrm{T}}$ contained straight-chain, and iso- and anteiso-branched components and a high proportion of saturated components, with unsaturated fatty acids present in small amounts: $\mathrm{C}_{16: 0}$ $(21.34 \%)$, iso- $\mathrm{C}_{16: 0}(19.01 \%)$, anteiso- $\mathrm{C}_{15: 0}(18.14 \%)$, iso$\mathrm{C}_{15: 0}(7.36 \%)$, anteiso- $\mathrm{C}_{17: 0}(6.97 \%)$, iso- $\mathrm{C}_{14: 0}(6.18 \%)$, $\mathrm{C}_{15: 0}(5.20 \%), \mathrm{C}_{17: 0}(3.25 \%)$, iso- $\mathrm{C}_{17: 0}(2.81 \%)$ and $\mathrm{C}_{14: 0}$

Table 1. Cultural characteristics of strain $\mathrm{CCNWHQ} 0031^{\top}$ on various media (incubated for 7 days at $28^{\circ} \mathrm{C}$ )

\begin{tabular}{|c|c|c|c|c|c|c|c|}
\hline Characteristic & ISP 2 & ISP 3 & ISP 4 & ISP 5 & Nutrient agar & Czapek agar & $\begin{array}{c}\text { Bennett's } \\
\text { agar }\end{array}$ \\
\hline Growth & Good & Good & Good & Poor & Moderate & Moderate & Good \\
\hline Sporulation & None & Good & Good & Poor & Moderate & Moderate & Good \\
\hline \multicolumn{8}{|l|}{ Colour of: } \\
\hline Aerial mycelium & Waxy & Greyish-blue & White & White & White & Greyish-white & White \\
\hline Substrate mycelium & Brown & Brown & Brown & Greyish-white & Dark brown & Light brown & Brown \\
\hline Diffusible pigment & None & Light blue & Light navy blue & None & Light brown & Light navy blue & None \\
\hline
\end{tabular}


Table 2. Fatty acid composition (\%) of strain CCNWHO $0031^{\top}$ and S. caeruleatus GIMN4.002 ${ }^{\top}$

Strains: 1 , CCNWHQ $0031^{\mathrm{T}} ; 2$, GIMN4.002 ${ }^{\mathrm{T}}$.

\begin{tabular}{|c|c|c|}
\hline Fatty acid & 1 & 2 \\
\hline iso- $\mathrm{C}_{14: 0}$ & 6.18 & 7.31 \\
\hline $\mathrm{C}_{14: 0}$ & 1.10 & 4.37 \\
\hline iso- $\mathrm{C}_{15: 0}$ & 7.36 & 3.90 \\
\hline anteiso- $\mathrm{C}_{15: 0}$ & 18.14 & 10.46 \\
\hline $\mathrm{C}_{15: 0}$ & 5.20 & 3.67 \\
\hline iso- $\mathrm{C}_{16: 0}$ & 19.01 & 18.67 \\
\hline $\mathrm{C}_{16: 0}$ & 21.34 & 25.19 \\
\hline iso- $\mathrm{C}_{17: 0}$ & 2.81 & 0.89 \\
\hline anteiso- $\mathrm{C}_{17: 0}$ & 6.97 & 2.56 \\
\hline $\mathrm{C}_{17: 0}$ & 3.25 & 0.85 \\
\hline
\end{tabular}

$(1.10 \%)$ (Table 2). The predominant menaquinones were MK-9 $\left(\mathrm{H}_{8}\right) \quad(46.17 \%)$, MK-9 $\left(\mathrm{H}_{2}\right) \quad(11.92 \%), \quad$ MK- $9\left(\mathrm{H}_{4}\right)$ $(11.34 \%)$ and MK-9 $\left(\mathrm{H}_{6}\right)(4.98 \%)$, and MK-10 $\left(\mathrm{H}_{2}\right)$ $(16.02 \%)$. Phospholipid profiles mainly contained phosphatidylethanolamine, which belonged to phospholipid type II (Lechevalier et al., 1977) (Fig. S1). The DNA G + C content of strain CCNWHQ $0031^{\mathrm{T}}$ was $70.7 \mathrm{~mol} \%$.

The morphological and physiological characteristics of strain CCNWHQ $0031^{\mathrm{T}}$, including its cell-wall type, whole cell sugar pattern and fatty acid profile (Table 2), were also consistent with those of members of the genus Streptomyces (Williams et al., 1989).

To determine its phylogenetic position, the 16S rRNA gene sequence (1419 nt) of strain CCNWHQ $0031^{\mathrm{T}}$ was aligned with closely related Streptomyces species. The isolate was most closely related to Streptomyces caeruleatus GIMN4.002 ${ }^{\mathrm{T}}$, Streptomyces coeruleorubidus NBRC $12855^{\mathrm{T}}$, Streptomyces curacoi NBRC $12761^{\mathrm{T}}$ and Streptomyces lincolnensis NBRC $13054^{\mathrm{T}}$, with sequence similarities of $99.3,98.9,98.8$ and $98.0 \%$, respectively (Fig. 2).

Furthermore, DNA-DNA relatedness studies were carried out between strain CCNWHQ $0031^{\mathrm{T}}$ and these four most closely related type strains; DNA-DNA relatedness values were $56.6 \pm 0.4,50.3 \pm 0.6,49.8 \pm 0.7$ and $36.9 \pm 0.9 \%$, respectively, which were significantly lower than the $70 \%$ cut-off point recommended for the delineation of genomic species (Wayne et al., 1987).

Phenotypic characterization of strain CCNWHQ $0031^{\mathrm{T}}$ clearly showed that it differed from the most closely related species S. caeruleatus GIMN4.002 ${ }^{\mathrm{T}}$, S. coeruleorubidus NBRC $12855^{\mathrm{T}}$, S. curacoi NBRC $12761^{\mathrm{T}}$ and S. lincolnensis NBRC $13054^{\mathrm{T}}$ (Table 3). Moreover, a combination of physiological and biochemical characteristics enabled strain CCNWHQ $0031^{\mathrm{T}}$ to be distinguished from its closest phylogenetic neighbours.

Strain CCNWHQ $0031^{\mathrm{T}}$ grew well in Gause's synthetic liquid medium supplemented with $5.5 \mathrm{mM} \mathrm{Pb}^{2+}\left[\mathrm{Pb}\left(\mathrm{NO}_{3}\right)_{2}\right]$ and

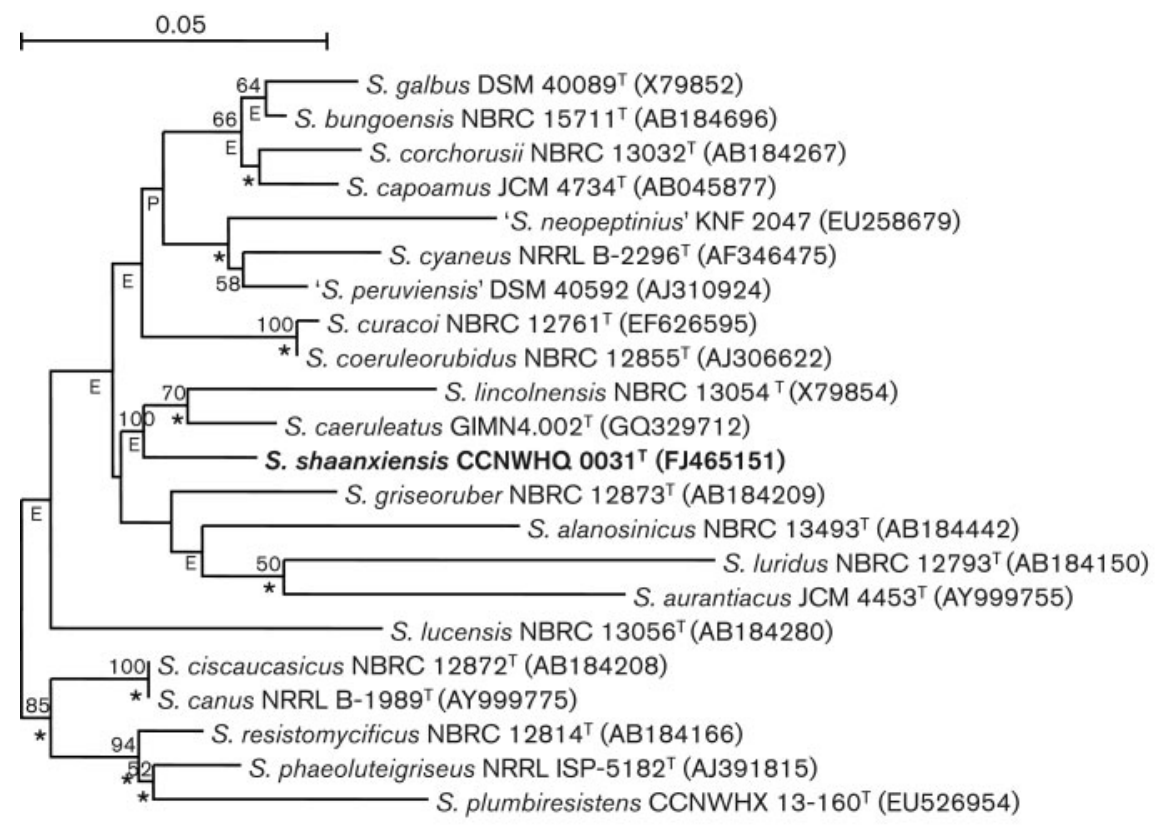

Fig. 2. Unrooted neighbour-joining phylogenetic tree based on almost complete $16 \mathrm{~S}$ rRNA gene sequences, showing the relationships between strain CCNWHQ $0031^{\top}$ and related species in the genus Streptomyces. E and P indicate the branches that were also found when the minimum-evolution and maximum-parsimony methods, respectively, were used; asterisks indicate branches that were recovered by all three methods. Accession numbers are given in parentheses. Bootstrap percentages (based on 1000 replications) are shown at the branch points; only values of $50 \%$ or above are given. Bar, 0.05 substitutions per nucleotide position. 
Table 3. Phenotypic characteristics of strain CCNWHQ $0031^{\top}$ and members of the most closely related Streptomyces species

Strains: 1, CCNWHQ $0031^{\mathrm{T}}$; 2, S. caeruleatus GIMN4.002 ${ }^{\mathrm{T}}$; 3, S. coeruleorubidus NBRC $12855^{\mathrm{T}}$; 4, S. curacoi $\mathrm{NBRC} 12761^{\mathrm{T}}$; 5, S. lincolnensis NBRC $13054^{\mathrm{T}}$. All strains are positive for assimilation of starch, D-galactose, glycerol, glucose and mannitol as sole carbon sources and for assimilation of L-phenylalanine, asparagine, alanine, L-methionine and L-threonine as sole nitrogen sources. All strains degrade Tween 80 . All strains grow with $2 \%$ $\mathrm{NaCl}$, but not with $5 \% \mathrm{NaCl}$. All strains grow at $28-37{ }^{\circ} \mathrm{C}$ and $\mathrm{pH} 6-11 .+$, Positive; - , negative; $(+)$, weakly positive. All data were determined in the present study except data for strain S. caeruleatus GIMN4.002 ${ }^{\mathrm{T}}$, which were from Zhu et al. (2011).

\begin{tabular}{|c|c|c|c|c|c|}
\hline Characteristic & 1 & 2 & 3 & 4 & 5 \\
\hline \multicolumn{6}{|c|}{ Culture characteristics on Gause's synthetic agar: } \\
\hline Aerial mycelium colour & Light greyish-blue & White & Light grey & Greyish-green & White \\
\hline Substrate mycelium colour & Dark blue & Reddish-brown & Light yellow & Dark grey & Light saffron \\
\hline Spore chain morphology & Spiral & Spiral & Spiral & Spiral & Straight or flexuous \\
\hline Diffusible pigment production & Dark blue & Dark blue & None & None & None \\
\hline \multicolumn{6}{|l|}{$\begin{array}{l}\text { Assimilation of sole carbon sources } \\
(1.0 \%, \mathrm{w} / \mathrm{v}) \text { : }\end{array}$} \\
\hline D-Fructose & + & + & + & - & - \\
\hline Lactose & + & + & $(+)$ & - & + \\
\hline Raffinose & $(+)$ & - & $(+)$ & - & + \\
\hline Ribose & - & - & $(+)$ & - & - \\
\hline Sucrose & + & - & + & $(+)$ & + \\
\hline \multicolumn{6}{|c|}{$\begin{array}{l}\text { Assimilation of sole nitrogen sources } \\
(1.0 \%, \mathrm{w} / \mathrm{v}) \text { : }\end{array}$} \\
\hline Arginine & $(+)$ & - & $(+)$ & - & $(+)$ \\
\hline Histidine & - & - & - & - & $(+)$ \\
\hline Tween 20 decomposition & + & + & + & $(+)$ & - \\
\hline \multicolumn{6}{|l|}{ Growth at/with: } \\
\hline $20{ }^{\circ} \mathrm{C}$ & + & $(+)$ & + & + & + \\
\hline $45{ }^{\circ} \mathrm{C}$ & - & - & + & + & - \\
\hline $\mathrm{pH} 5$ & + & - & - & + & - \\
\hline pH 12 & - & + & - & + & + \\
\hline $3 \% \mathrm{NaCl}$ & + & + & + & + & - \\
\hline $4 \% \mathrm{NaCl}$ & - & - & + & + & - \\
\hline Gelatin liquefaction & - & - & - & + & + \\
\hline Milk coagulation & - & - & - & - & + \\
\hline Milk peptonization & + & + & + & + & - \\
\hline $\mathrm{H}_{2} \mathrm{~S}$ production & $(+)$ & + & + & - & + \\
\hline Melanin production & $(+)$ & - & - & $(+)$ & + \\
\hline Starch hydrolysis & $(+)$ & + & + & + & + \\
\hline Nitrate reduction & $(+)$ & - & + & + & - \\
\hline \multicolumn{6}{|l|}{ Heavy metal resistance: } \\
\hline $\mathrm{Zn}^{2+}(20 \mathrm{mM})$ & + & - & - & - & - \\
\hline $\mathrm{Pb}^{2+}(5.5 \mathrm{mM})$ & + & - & + & - & $(+)$ \\
\hline
\end{tabular}

$20 \mathrm{mM} \mathrm{Zn}{ }^{2+}\left(\mathrm{ZnCl}_{2}\right)$. In contrast, S. lincolnensis NBRC $13054^{\mathrm{T}}$ grew poorly in the presence of $5.5 \mathrm{mM} \mathrm{Pb}^{2+}$, and $S$. caeruleatus GIMN4.002 ${ }^{\mathrm{T}}$ and S. curacoi NBRC $12761^{\mathrm{T}}$ could not grow in the presence of $5.5 \mathrm{mM} \mathrm{Pb}^{2+}$.

Taken together, all the genotypic and phenotypic data suggest that strain CCNWHQ 0031 ${ }^{\mathrm{T}}$ represents a novel species of the genus Streptomyces, for which the name Streptomyces shaanxiensis sp. nov. is proposed.

\section{Description of Streptomyces shaanxiensis sp. nov.}

Streptomyces shaanxiensis (sha.an.xi.en'sis. N.L. masc. adj. shaanxiensis pertaining to Shaanxi, a province of north-western
China, the geographical location from where the type strain was isolated).

Aerobic, Gram-positive, forms light greyish-blue aerial mycelium, dark blue substrate mycelium and dark blue diffusible pigment on Gause's synthetic agar (Fig. S2). Produces Spirales spore chains with spiny, light blue spores. Growth occurs at $20-37^{\circ} \mathrm{C}$, at $\mathrm{pH} 5.0-11.0$ and in the presence of $0-3 \%(\mathrm{w} / \mathrm{v}) \mathrm{NaCl}$. Optimum growth occurs at $28{ }^{\circ} \mathrm{C}$, at $\mathrm{pH} 7.5$ and in the presence of $1 \%(\mathrm{w} / \mathrm{v}) \mathrm{NaCl}$. Utilizes starch, mannitol, lactose, D-galactose, sucrose, glycerol and D-fructose as carbon sources. L-Phenylalanine, alanine, L-threonine and asparagine are utilized as nitrogen sources. Cell wall contains LL-DAP, traces of meso-DAP and glycine (cell wall type I). Whole-cell hydrolysates contain the 
diagnostic sugars mannose and arabinose, with small quantities of xylose. Cell membranes contain phosphatidylethanolamine and the phospholipid pattern is type II. The major cellular fatty acids $(>5 \%)$ are $\mathrm{C}_{16: 0}$, iso- $\mathrm{C}_{16: 0}$, anteiso- $\mathrm{C}_{15: 0}$, iso- $\mathrm{C}_{15: 0}$, anteiso- $\mathrm{C}_{17: 0}$, iso- $\mathrm{C}_{14: 0}$ and $\mathrm{C}_{15: 0}$. Other physiological and biochemical properties are listed in Table 3.

The type strain, CCNWHQ 0031 ${ }^{\mathrm{T}} \quad$ (=CCNWT) $0031^{\mathrm{T}}=\mathrm{JCM} 16925^{\mathrm{T}}=$ ACCC $41873^{\mathrm{T}}$ ), was isolated from a sewage irrigation area from Shaanxi province, northwestern China. The DNA G $+\mathrm{C}$ content of the type strain is $70.7 \mathrm{~mol} \%$.

\section{Acknowledgements}

We are grateful to Ms Hong-hui Zhu for providing the reference strain of Streptomyces caeruleatus GIMN4 ${ }^{\mathrm{T}}$. This research was supported by projects from the National Science Foundation of China (31070444, 30970003, 30900215 and 30630054), National Basic Research Program of China (2010CB126502) and PCSIRT (IRT0748) of China.

\section{References}

Atlas, R. M. (1993). Handbook of Microbiological Media. Edited by L. C. Parks. Boca Raton, FL: CRC Press.

Bérdy, J. (2005). Bioactive microbial metabolites. J Antibiot (Tokyo) 58, 1-26.

Bystrykh, L. V., Fernández-Moreno, M. A., Herrema, J. K., Malpartida, F., Hopwood, D. A. \& Dijkhuizen, L. (1996). Production of actinorhodin-related "blue pigments" by Streptomyces coelicolor A3(2). J Bacteriol 178, 2238-2244.

Chun, J. \& Goodfellow, M. (1995). A phylogenetic analysis of the genus Nocardia with 16S rRNA gene sequences. Int J Syst Bacteriol 45, 240-245.

Chun, J., Lee, J. H., Jung, Y., Kim, M., Kim, S., Kim, B. K. \& Lim, Y. W. (2007). EzTaxon: a web-based tool for the identification of prokaryotes based on $16 \mathrm{~S}$ ribosomal RNA gene sequences. Int J Syst Evol Microbiol 57, 2259-2261.

Collins, M. D. (1985). Isoprenoid quinone analysis in classification and identification. In Chemical Methods in Bacterial Systematics, pp. 267-287. Edited by M. Goodfellow \& D. E. Minnikin. London: Academic Press.

De Ley, J., Cattoir, H. \& Reynaerts, A. (1970). The quantitative measurement of DNA hybridization from renaturation rates. Eur $J$ Biochem 12, 133-142.

Eguchi, T., Takada, N., Nakamura, S., Tanaka, T., Makino, T. \& Oshima, Y. (1993). Streptomyces bungoensis sp. nov. Int J Syst Bacteriol 43, 794-798.

Felsenstein, J. (1985). Confidence limits on phylogenies: an approach using the bootstrap. Evolution 39, 783-791.

Fitch, W. M. (1971). Toward defining the course of evolution: minimum change for a specific tree topology. Syst Zool 20, 406-416.

Goodfellow, M. (1971). Numerical taxonomy of some nocardioform bacteria. J Gen Microbiol 69, 33-80.

Gordon, R. E. \& Minm, J. M. (1962). The type species of the genus Nocardia. J Gen Microbiol 27, 1-10.

Kämpfer, P. \& Kroppenstedt, R. M. (1996). Numerical analysis of fatty acid patterns of coryneform bacteria and related taxa. Can $J$ Microbiol 42, 989-1005.
Kelly, K. L. (1964). Inter-Society Color Council - National Bureau of Standards Color Name Charts Illustrated with Centroid Colors. Washington, DC: US Government Printing Office.

Kimura, M. (1980). A simple method for estimating evolutionary rates of base substitutions through comparative studies of nucleotide sequences. J Mol Evol 16, 111-120.

Kumar, S., Tamura, K. \& Nei, M. (2004). MEGA3: integrated software for molecular evolutionary genetics analysis and sequence alignment. Brief Bioinform 5, 150-163.

Lechevalier, H. A. \& Lechevalier, M. P. (1970). A critical evaluation of the genera of aerobic actinomycetes. In The Actinomycetales, pp. 393405. Edited by H. Prauser. Jena: VEB Gustav Fischer.

Lechevalier, H. A. \& Lechevalier, M. P. (1980). The chemotaxonomy of actinomycetes. In Actinomycete Taxonomy (Special Publication 6), pp. 277-284. Edited by A. Dietz \& D. W. Thayer. Arlington, VA: Society of Industrial Biology.

Lechevalier, M. P., De Bièvre, C. \& Lechevalier, H. A. (1977). Chemotaxonomy of aerobic actinomycetes: phospholipid composition. Biochem Syst Ecol 5, 249-260.

Margalith, P. Z. (1992). Pigment Microbiology, pp. 111-114. London: Chapman \& Hall.

Marmur, J. \& Doty, P. (1962). Determination of the base composition of deoxyribonucleic acid from its thermal denaturation temperature. J Mol Biol 5, 109-118.

Meyers, P. R., Porter, D. S., Omorogie, C., Pule, J. M. \& Kwetane, T. (2003). Streptomyces speibonae sp. nov., a novel streptomycete with blue substrate mycelium isolated from South African soil. Int J Syst Evol Microbiol 53, 801-805.

Meyers, P. R., Goodwin, C. M., Bennett, J. A., Aken, B. L., Price, C. E. \& van Rooyen, J. M. (2004). Streptomyces africanus sp. nov., a novel streptomycete with blue aerial mycelium. Int J Syst Evol Microbiol 54, 1531-1535.

Minnikin, D. E., Patel, P. V., Alshamaony, L. \& Goodfellow, M. (1977). Polar lipid composition in the classification of Nocardia and related bacteria. Int J Syst Bacteriol 27, 104-117.

Pszczolla, D. (1998). The ABC's of nutraceutical ingredients. Food Technol 53, 30-37.

Rzhetsky, A. \& Nei, M. (1993). Theoretical foundation of the minimum-evolution method of phylogenetic inference. Mol Biol Evol 10, 1073-1095.

Saitou, N. \& Nei, M. (1987). The neighbor-joining method: a new method for reconstructing phylogenetic trees. Mol Biol Evol 4, 406425 .

Shirling, E. B. \& Gottlieb, D. (1966). Methods for characterization of Streptomyces species. Int J Syst Bacteriol 16, 313-340.

Thompson, J. D., Gibson, T. J., Plewniak, F., Jeanmougin, F. \& Higgins, D. G. (1997). The CLUSTAL_X windows interface: flexible strategies for multiple sequence alignment aided by quality analysis tools. Nucleic Acids Res 25, 4876-4882.

Trejo, W. H. \& Bennett, R. E. (1963). Streptomyces species comprising the blue-spore series. J Bacteriol 85, 676-690.

Tsukamura, M. (1966). Adansonian classification of mycobacteria. J Gen Microbiol 45, 253-273.

Van de Peer, Y. \& De Wachter, R. (1994). TREECON for Windows: a software package for the construction and drawing of evolutionary trees for the Microsoft Windows environment. Comput Appl Biosci 10, 569-570.

Waksman, S. A. \& Henrici, A. T. (1943). The nomenclature and classification of the actinomycetes. J Bacteriol 46, 337-341.

Wayne, L. G., Brenner, D. J., Colwell, R. R., Grimont, P. A. D., Kandler, O., Krichevsky, M. I., Moore, L. H., Moore, W. E. C., Murray, R. G. E. \& 
other authors (1987). International Committee on Systematic Bacteriology. Report of the ad hoc committee on reconciliation of approaches to bacterial systematics. Int J Syst Bacteriol 37, 463-464.

Williams, S. T., Goodfellow, M., Alderson, G., Wellington, E. M., Sneath, P. H. \& Sackin, M. J. (1983). Numerical classification of Streptomyces and related genera. J Gen Microbiol 129, 1743-1813.

Williams, S. T., Goodfellow, M. \& Alderson, G. (1989). Genus Streptomyces Waksman and Henrici 1943, 339 ${ }^{\mathrm{AL}}$. In Bergey's Manual of Systematic Bacteriology, vol. 4, pp. 2452-2492. Edited by
S. T. Williams, M. E. Sharpe \& J. G. Holt. Baltimore: Williams \& Wilkins.

Zhu, H. H., Guo, J., Yao, Q., Yang, S. Z., Deng, M. R., Phuong, T. B., Hanh, V. T. \& Ryan, M. J. (2007). Streptomyces vietnamensis sp. nov., a streptomycete with violet-blue diffusible pigment isolated from soil in Vietnam. Int J Syst Evol Microbiol 57, 1770-1774.

Zhu, H.-H., Guo, J., Yao, Q., Yang, S.-Z., Deng, M.-R. \& Li, T.-H. (2011). Streptomyces caeruleatus sp. nov., with dark blue diffusible pigment. Int J Syst Evol Microbiol 61, 507-511. 